\title{
Judges' Continuing Construction in Enterprise-Conditioned Employer Dismissal in Germany: Specific Research of the Proportion Principle ${ }^{1}$
}

\author{
Jianhong Fan \\ University of Macau, Macau, China \\ Email: jhfan@umac.mo
}

Received 2 September 2014; revised 19 October 2014; accepted 6 November 2014

Copyright (C) 2014 by author and Scientific Research Publishing Inc.

This work is licensed under the Creative Commons Attribution International License (CC BY).

http://creativecommons.org/licenses/by/4.0/

(c) (i) Open Access

\section{Abstract}

A common theme must be ensuring equity to protecting the job security of employees, when the enterprise owners implement the dismissal right due to enterprises reasons. There are yet many problems needing to be solved in the interpretation, application, construction and supplementation of the norm of "social rationality" according to German Federal Dismissal Protection Statute. It is important to Germany itself but will also have far-reaching effects on foreign countries that have enterprise in Germany. Nevertheless, it is not easy for designing a new control structure for such dismissal. In this paper, a legislative space of social rationality could be continuingly constructed or supplemented successfully. This should thus be welcomed by international judges, lawyers and citizens.

\section{Keywords}

Dismissal Right, Social Rationality, Urgent Enterprise Need, Continuing Construction of Legislation Space, Opinio Juris, Principle of Proportionality, Control Structure

\section{Introduction}

When the enterprise owners implement the dismissal right due to enterprises reasons, they should conform to the norm of "social rationality" (sozial grechtfertigt) according to German Federal Dismissal Protection Statute (KschutzG) (Hereinafter referred to as Dismissal Protection Statue). The norm of social rationality is a concept

${ }^{1}$ I would like to dedicate this essay for Beijing Law Review to my mother, YANG, Tingfang (12.06.1935-20.06.2013). 
of legal technique (rectstechnischer Begriff) and a loophole left by legislators, and its content needs continuing construction or supplement. In Germany, whether the judges can continuingly construct or supplement this legislative loophole by judgments? If they can, what is the premise and scope for such continuing construction and supplementation (Rechtsfortbildung/Rechtsergänzung/Rechtsneubildung)? And then which way and method can be used for judges to seek for a certain standard and to construct and supplement the norm? How to resolve the problem of continuing construction and supplementation of legislation space, which exist within the standard of social rationality, deeply and concretely in structure? These are some complicated problems which we need to resolve firstly in this paper.

\section{Legislative Standard of Limits of Dismissal and Instrumental Options for Judges' Continuing Construction}

Legislators have only proposed a standard of “social rationality” to restrict dismissals. So, if you don't intend to be a "Fachidiot" (the one who applies the law without any thinking), then you need to choose some kinds of justification mode on which the effects of law are based.

\subsection{The Legislative Standard: Social Rationality and Its Definition}

Legislators have proposed the concepts of social rationality and non-social rationality under Article 1 Sections 2 and 3 of the Dismissal Protection Statute (Preis, 1987: S. 101 f.). However, social rationality and non-social rationality are legal technical concepts ${ }^{2}$ that involve continuing construction (Rechtsfortbildungsbedürftig) or supplementation (ergänzungdsbedürftig). Judges can solve issues that require only these solutions as long as they turn to classical cases (judicial precedents are often binding and followed within the Anglo-American system) and legal science. Other common provisions (Rühers, 2002: Rn. 836; Hedemann, 1933) are problematic. How does one dispose of the application relationship between "good social practice" (Article 138 Section 1 of the German Civil Code), "good faith" (Article 242 of the Civil Code) and social rationality? The solutions of continuing construction or supplementation would be questioned if they were unrelated to the issue. To solve this problem, we must consider the "legislative privilege" that is often invoked in the judicial practices of a continental legal system. Article 13 Section 2 of the Dismissal Protection Statute proclaims clearly that "good social practice" (Article 138 Section 2 of the Civil Code) can be applied independently and simultaneously. Apart from the Dismissal Protection Statute, what is the applicable scope of the "good faith" principle (Article 242 of the Civil Code)? According to the literal meaning of Article 242, the principle regulates the actions a debtor should take. However, legal practice and theory both agree that the principle has exceeded its literal meaning and become applicable to legal life in its entirety. In other words, everyone should comply with the good faith principle in exercising their rights and performing their obligations. The principle is meaningful to the Dismissal Protection Statute. Does this mean that there are some conflicts between the applications of principles? To answer this question, we turn to the common provisions of legislative privilege. First, legal practitioners have a duty to examine whether legislators embody the principle. This means that they should determine the rules or articles in which the principle materializes. Doing so may resolve any conflicts that arise. Second, if the legislators do not embody the principle, concrete and particular principles are applied prior to the abstract and common ones unless they are absolute (e.g., "dignity is inviolable, and it is the duty of all organs of the state authority to respect and protect human dignity") or exclude any other general or specific principles (Alex, 1979: S. 59 ff.). In this article, the relationship between the good faith principle and social rationality of the Dismissal Protection Statute is not the same as that between general and special principles (kein lex generalis-lex specialis-Verhältnis). The idea of dismissal protection does not arrive completely from Article 242 of the Civil Code. The good faith principle can be invoked (Siebert, 1960: S. 1029 ff.) only when it has been embodied by the Dismissal Protection Statute and when an employee lodges a complaint according to Article 1 Section 2 of the Statute. Of course, the application of the spirit of good faith can be found either within or beyond the scope of the Statute, especially when many of the concrete rules are legislated based on the principle's spirit. Nevertheless, different theories take effect if the applicable issue does not refer to the social rationality clause of the dismissal and is examined independently by virtue of the good faith clause. The application of social rationality, good social practice and good faith under the Dismissal Protection Statute has not been ambiguous until now. The issue of how to continuingly construct and supplement social rationality is discussed further later in this paper.

${ }^{2}$ Zur Problematik von unbestimmten Rechtsbegriffen, Hoffmann ZfA 1970, 66 ff. 


\subsection{Social Rationality and the Categories of Dismissal Causes}

Not all of the social rationalities of dismissal need be continuingly constructed or supplemented by judges. Legislators have made room for the social rationality of dismissal in some respects. The second and third sentences of Article 1 Section 2 and the first sentence of Article 1 Section 3 of the Dismissal Protection Statute ${ }^{3}$ have made this point clearly. Article 1 Section 2 of the Dismissal Protection Statute deems that "if the dismissal is not able to provide the causes of the person or activity, or is unable to provide a cause of urgent enterprise need, which conflicts with maintaining the labor relationship, then it is an non-social-rational dismissal." Social rationality requires that the aforementioned categories of dismissal causes must be provided, and that the second and third sentences of Article 1 Section 2 and the first sentence of Article 1 Section 3 must be satisfied. Even with these limitations, the legislative room for social rationality refers to the types of dismissal causes and is far from enriched. However, to judge whether a cause is non-social-rational depends on whether it complies with a concrete definition of social rationality.

In terms of the causes of dismissals by enterprises, the first sentence of Article1 Section 2 mentions the "urgent enterprise need". Does the word "urgent" reflect the materialization of social rationality by legislators? If so, does this mean that social rationality can be justified through the satisfaction of the urgent enterprise need? What are enterprise needs, and are judges capable of or entitled to examine and verify such needs? Although the word "urgent" is important, it does not constitute a concrete reason in line with social rationality. Rather, it is merely a conversion of words that requires materialization much like the expression of an "important reason" in the first sentence of Article 626 Section1 on special dismissal in the Civil Code. It also requires an embodiment action on behalf of legislators (other than those who give up the action) and the help of judges and scholars through the use of certain tools after analyzing the ends and means. How do legislations, legal precedents and legal theories objectify the reasonable causes of dismissal? This question should be addressed based on judges' provision of continuing construction or supplementation for social rationality.

\subsubsection{The Space Left to the Judicature by Legislators}

Social rationality refers to the provision of rational causes or reasons according to the first sentence of Article 1Section 2 of the Dismissal Protection Statute. These reasons should not infract the second and third sentences of Article 1 Sections 2 and 3 of the Statute. This provision settles the questions through the use of legal inference technology (juristische Subsumierungstechnik, Syllogismus). However, under the different conditions of facts and laws, judges encounter various spaces as a result of the dismissal legal provisions enacted by legislators. That is, the space for a judge to estimate whether a dismissal reason is rational is affected by the legislator. Other than those provided in contracts, some of the limitations to dismissal provided by legislators are given as follows ${ }^{4}$.

\section{1) Provisions on Absolute and Conditional Limitations}

Legislators have for bidden the dismissal of pregnant women and parturient women with children under 4 months old ${ }^{5}$; the dismissal of severely disabled persons without preliminary agreement from important relief agencies $^{6}$; the dismissal of members of the Enterprise Representative Assembly, teenagers, trainee representatives $^{7}$ and entrusted custodians of severely disabled persons by ordinary means ${ }^{8}$ and any dismissal under disa-

\footnotetext{
${ }^{3}$ Vgl.: §1 Abs. 2, S. 2 (1) a: §95 BetriebsVG Auswahlrichtlinien: (1) Richtlinien über die personelle Auswahl bei Einstellungen, Versetzungen, Umgruppierungen und Kündigungen bedürfen der Zustimmung des Betriebsrats. Kommt eine Einigungüber die Richtlinien oder ihren Inhalt nicht zustande, so entscheidet auf Antrag des Arbeitgebers die Einigungsstelle. Der Spruch der Einigungsstelle ersetzt die Einigung zwischen Arbeitgeber und Betriebsrat. (2) In Betrieben mit mehr als 500 Arbeitnehmern kann der Betriebsrat die Aufstellung von Richtlinienüber die bei Maßnahmen des Absatzes 1 Satz 1 zu beachtenden fachlichen und persönlichen Voraussetzungen und sozialen Gesichtspunkte verlangen. Kommt eine Einigungüber die Richtlinien oder ihren Inhalt nicht zustande, so entscheidet die Einigungsstelle. Der Spruch der Einigungsstelle ersetzt die Einigung zwischen Arbeitgeber und Betriebsrat. (3) Versetzung im Sinne dieses Gesetzes ist die Zuweisung eines anderen Arbeitsbereichs, die voraussichtlich die Dauer von einem Monat überschreitet, oder die mit einer erheblichen Änderung der Umstände verbunden ist, unter denen die Arbeit zu leisten ist. Werden Arbeitnehmer nach der Eigenart ihres Arbeitsverhältnisses üblicherweise nicht ständig an einem bestimmten Arbeitsplatz beschäftigt, so gilt die Bestimmung des jeweiligen Arbeitsplatzes nicht als Versetzung. Auch BAG (Bundesarbeitsgericht). Beschluss vom 22.04.2003, vom 31.05.2005, vom 26.07.2005, vom 22.11.2005.

${ }^{4}$ Vertragliche Kündigungsschranken können als solche enthalten: gesetzliche, kollektiv- und einzelvertragliche Kündigungsfristen; tatbestandlich festumrissene kollektiv- und einzelvertragliche Ausschlüsse oder sonstige Beschränkungen der ordentlichen Küendigung.

${ }^{5}$ Vgl.: $§ 9$ MuSchG.

${ }^{6}$ Vgl.: $\$ 15$ ff. SchwbG.

${ }^{7}$ Vgl.: $§ 15 \mathrm{KSchG}$

${ }^{8}$ Vgl.: $\$ 26$ Abs. 3 SchwbG i.V.m. §15 KSchG.
} 
greement of the Enterprise Representative Assembly (excepting interference from the Labor Court) (§103 BetrVG ${ }^{9}$ ). Assemblymen are also protected based on the definitions found in Article 48 Section 2 (Art. 48 Abs. 2 GG) of the Basic Law and Article 2 Section 3 (§2 Abs. 3 AbgG) of the Assemblyman Law (KR-Weigand, Rn. 10 ff.; KR-Friedrich, $\$ 13 \mathrm{KSchG}$, Rn. 176 ff.). Other provisions are forbidden based on other legal stipulations (§26 Abs. 3 SchwbG; §18 BErzGG ${ }^{10}$ ). The provisions of conditional limitation exist on a massive scale ${ }^{11}$. According to legal precedents ${ }^{12}$ and theories (KR-Becker, §1 KSchG, 2007: Rn. 139, 152; Stahlhacke/Preis, 1991: Rn. 459, 525.), absolute limitation provisions also exist in line with the second and third sentences of Article 1 Sections 2 and 3. (Of course, there are different opinions on recognizing the third sentence of Article 1 Section 2 as an absolute limitation) ${ }^{13}$. Absolute limitation provisions result from legislators confirming that their consideration of the balance of interests is correct and relatively unchangeable. As Germany adopts the continental law system, people do not think that the judgment of German judges could be better than that of legislators, and also deny that the rights resulting from a power division should be awarded to judges to make laws. They thus infer that the concrete justice values reflected by German judges are either lesser or more important than those that have been recognized and identified by legislators.

\section{2) Uncertain Legal Concepts become Legislative Spaces or Dismissal Reason Loopholes}

As mentioned previously, three kinds of dismissal causes or reasons rooted in social irrationality create legislative spaces, and concrete reasons based on social rationality are the keys to filling them. Legislators have already given specific and definite stipulations on prohibition and limitation in some situations, and within the scope of German law, judges do not have the freedom to provide continuing construction or supplementation for a legislative space (or loopholes). However, looking at the dismissal reasons in the first sentence of Article 1 Section 2 of the Dismissal Protection Statute, the legislators seem to have left spaces on purpose. The legislators cannot fix all of the specific dismissal reasons for dynamic and ever-developing social situations, and can only stipulate the categories of dismissal reasons. Because legislators cannot and are not required to solve current and future problems or attend to every aspect without emphasis, such problems must be sorted out in a more principled manner. Against the background of a constitution, the structure and density of rules are settled based on the scope of the legislative organs' control over legal practice organizations, i.e., the width of the scope in which the basic rights in a country under the rule of law are set (Hermann, 1982: S. 106). The dispositions of the structure and density of rules are usually embodied in legislative technology. For example, special dismissal reasons are stipulated in Article 626 of the Civil Code, and among these reasons the expression of a "requirement of important reasons"14 is a legal technical concept without specific settings. This concept comprises the spaces purposely left by legislators for judges to provide continuing construction or supplementation.

Because legislators only provide categories of dismissal reasons or use legal technical concepts without specific settings, they cannot stipulate the connotations of social rationality and consciously leave legislative spaces for judges to conduct provide continuing construction or supplementation. Legislators concretize real dismissal reasons (Echte Kündigungsgründe) and have given up concretizing unreal dismissal reasons so that they may be adjusted to the complexity of the legal developments brought on by continuing construction or supplementation.

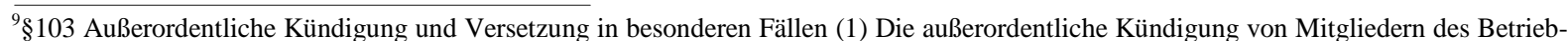
srats, der Jugend- und Auszubildendenvertretung, der Bordvertretung und des Seebetriebsrats, des Wahlvorstands sowie von Wahlbewerbern bedarf der Zustimmung des Betriebsrats. (2) Verweigert der Betriebsrat seine Zustimmung, so kann das Arbeitsgericht sie auf Antrag des Arbeitgebers ersetzen, wenn die außerordentliche Kündigung unter Berücksichtigung aller Umstände gerechtfertigt ist. In dem Verfahren vor dem Arbeitsgericht ist der betroffene Arbeitnehmer Beteiligter. (3) Die Versetzung der in Absatz 1 genannten Personen, die zu einem Verlust des Amtes oder der Wählbarkeit führen würde, bedarf der Zustimmung des Betriebsrats; dies gilt nicht, wenn der betroffene Arbeitnehmer mit der Versetzung einverstanden ist. Absatz 2 gilt entsprechend mit der Maßgabe, dass das Arbeitsgericht die Zustimmung zu der Versetzung ersetzen kann, wenn diese auch unter Berücksichtigung der betriebsverfassungsrechtlichen Stellung des betroffenen Arbeitnehmers aus dringenden betrieblichen Gründen notwendig ist. Auch Vgl.: BGH, Urteil vom 24.11.2005, 2AZR, 584/04.

${ }^{10}$ Vgl. §2, 10 ArbPISchG, §78 ZivildienstG, §2 EignungsübungsG.

${ }^{11}$ Ausschluß der ordentlichen Kündigung von Berufsausbildungsverhältnissen nach Ablauf der Probezeit gem. §15 Abs. 2 BBiG; Verbot der Kündigung des Arbeitsverhältnisses zwischen Verleiher und Leiharbeitnehmer durch den Verleiher, wenn der Verleiher den Leiharbeitnehmer innerhalb von drei Monaten nach Beendigung des Arbeitsverhältnisses erneut einstellt gem. Art. 1 §9 Nr. 3 AUEH; der sogenannte Massenkündigungsschutz gem. §17 ff. KSchG; Verbot der Kündigung ohne vorherige Anhörung des Betriebsrats gem. §102 Abs. 1 BetrVG bzw. des Personalrats aufgrund entsprechender Vorschriften des Personalvertretungsrechts; Verbot der Kündigung wegen Betriebsübergangs gem. 613a Abs. 4 BGB; Verbot der Kündigung eines Arbeitnehmers wegen des Ausscheidens eines anderen Arbeitnehmers bei Arbeitsplatzteilung gem. §5 Abs. 2 BeschFG 1985; Verbot der Kündigung eines Arbeitnehmers wegen zulässiger Rechtsausübung gem. §612a BGB.

${ }^{12}$ AG vom 13.9.1973-2 AZR 601/72-AP Nr. 2 zu §1 KSchG 1969 unter II.7.

${ }^{13}$ Vgl. wegen der danach anzustellenden Zumutbarkeitserwägungen, vgl.: Preis, §6V., S. 93 f.; §9 IV.1.a), S. 146 ff.; kritisch auch Gamillscheg I, Nr. 230 a), S. 482.

${ }^{14}$ Schönfelder, Deutsche Gesetze, Art. 626 BGB, C. H. Bach, München 1997.
} 


\subsubsection{The Premise and Methods of Judges' Continuing Construction of Legislative Space}

Because legislators find it impossible to enumerate complex dismissal reasons that match with social rationality and thereby define it specifically, legal rules have left spaces for judges to administer individual justice (Einzelfallgerechtigkeit) (Engisch, 1977: S. 106 ff.; Hirschberg, 1981: S. 201 Fn. 103.). How judges can continuingly construct or supplement dismissal reasons and how widely their actions can spread according to the second sentence of Article 1 Section 2 of the Dismissal Protection Statute are problematic. Further, whether a judge can use case groups or legal principles to fill the spaces left by legislators also presents a problem. We should clarify the premise behind judges' continuing construction or supplementation of legislative space or loopholes. First, whether German law allows such continuing construction and supplementation should be clarified legally. Article132 Section 4 of Germany's Organic Law of Court, Article11 Section 4 of the Rules of the Administrative Court and Article45 Section4 of the Labor Court Law clearly confer the power to continuingly construct laws to courts, and also mention the factor of judicial unification security. Article 1 Sections 2 and 3 of the Swiss Civil Code circa 1907 stated that customs law and the legislative role of judges should be used successively to address the provision of continuing construction according to current doctrines and tradition. Therefore, there is indeed a legal basis for the continuing construction or supplementation of legislative spaces or loopholes in German law. Second, we must concretely analyze the application problems facing judges so that we may clarify the situations judges confront.

\section{1) The Essence and Premise of Judges' Continuing Construction of Legislative Space}

In terms of jurisprudence, judges must fulfill three tasks when applying the law.

a) Reasoning

They must thoughtfully interpret and apply the law in line with the legislator's original intention (Rüthers, 2002: Rn. 828 f.; Heck, 1914: S. 19 ff.). When legislators leave no legislative space and consider every interest in each case, judges must verify the facts using the law and apply the law through reason (subsumieren).

b) Further Development of the Law

They must continuingly construct (Rechtsfortbildung) or supplement (Rechtsergänzung/Rechtsneubildung) the spaces intentionally left by legislators (Rüthers, 2002: Rn. 828 f.; Schneider, 1972: S. 335 f., 339 ff.) According to Larenz, continuing construction or supplementation is essentially "the acceptance and development of new legal thoughts which the law reveals, and these thoughts are realized through judicial decisions. It is beyond initial program of the law, and is more or less amendments of the initialprogram."15 The decision in the Soraya case (Volume 34 of the Judgments of the Federal Constitution Court of Germany) identified for the first time that judges are entitled to continuingly construct and supplement legal loopholes. In reality, legislative space (usually created intentionally) or loopholes (usually created unintentionally) have different manifestations. For example, they could constitute a lack of necessary elements in a provision, a lack of corresponding provisions among many others of a rule (such as Germany not integrating C.i.C into the Civil Code, but rather considering it as a kind of custom law) or a surplus of corresponding provisions in a code. Conflicts also arise between the rules in a code, or between rules in different codes. Further, some legal field (Rechtslücke) or area (Gebietslücke) loopholes may lack legislative stipulations (Rüthers, 2002: Rn. 846 f.; Engisch, 1977: S. 176 ff.). It is important to realize that a so-called "intention" is often the intention of the interpreters. If a judge were to consider an intention from both the legislator's angle and the angle of a future ideal legislation program, it would be possible for him to attribute the intentional gap to the legislator's neglect and deem it a legal loophole. Because it is impossible to understand a legislator's intention in the case of a loophole, the judge would have to create the necessary laws himself. However, the space left by legislators (intentionally or unintentionally) allows for continuing construction, supplementation and even development. The laws made by judges feature more content in unintentional cases. This certainly always relates to the guidance of legal consciousness, and whether judges fully understand a piece of legislation and provide continuing construction accordingly. The loopholes or spaces that legislators "intentionally" leave to judges generally include the following categories.

Firstly, Authorizing legal science theory and judicial practice to fill some legislative space, such as in the Labor Strike Law (Arbeitskampfrecht), which is part of economic administrative law. In such fields, the legislator does not create extra elaborate stipulations (Rüthers, 2002: Rn. 835). In some other traditional legal fields, whereas German law offers logical stipulations and theories, judicature offers very systematic and scientific explanations. Many professors and judges want to embody their legal willpower and imagination in these fields.

\footnotetext{
${ }^{15}$ Larenz’s Worte eingeführt von Bernd Rüthers, Rechtstheorie, Verlag Verlag. C. H. Beck OHG, München, Rn. 831 f.
} 
Secondly, Uncertain or general provisions in legal techniques, such as the provision of social rationality as mentioned previously and provisions with "important reasons" according to Article 626 Section 1 of the Civil Code. These provisions are enacted by legislators with the intent to adjust the development of a complex legal life and tomake judges provide construction or supplementation in the service of legal policies during different periods (Rüethers, 2002: Rn. 836.).

Thirdly, Legislator's silence after consideration. While similar to point (a), this point differs in that an already-made decision is silent. Unwilling to permit judges to create laws, the decisions act as invisible legislation boundaries. These decisions appear in the loopholes of norms rather than in those of entire laws and legal fields, which legislators neglect. For example, although Germany did not stipulate the foster duty between brothers and sisters on purpose, if a court decided that a gap existed and opted for continuing construction or supplementation, it would transgress an invisible boundary set by the legislators (Rüethers, 2002: Rn. 838). The first point (which authorizes legal theory and judges to fill legislative spaces) differs in that it allowslegal science and precedents to create laws in these fields. This is part of the reason why many jurists and judges are addicted to some fields of labor, administrative and economic law. This kind of indifference is certainly also restricted to the relevant regulations in Article 20 Section 30 f the Basic Law ${ }^{16}$. Silence after consideration is in fact a kind of backward reasoning (argumentum e silentio, argumentum e contrario), and functions as the expression of an objection in normal loophole situations. In cases of law (Gestzeslücke) and legal field (Rechtslücke) loopholes, legislators’ silence can be considered not as a result of consideration but as a result of the legislators' lack of foresight at the time of legislation.

c) Contrary to the Law

Contra legem is a Latin phrase meaning contrary to the law. They must judge legal violations (contra legem). After inquiring into the meaning of a piece of legislation's text and background and the relevant legal goals and system, a judge may find no space or loophole in the law, but find mistakes. During such an inquiry, because the Basic Law includes the rule of power separation and legislation prior to judicature, laws are revised based on a stringent premise. According to Article 100 Section 1 of the Basic Law, the court is responsible for submitting unconstitutional laws to the Constitutional Court (Rüthers, 2002: Rn. 827). In Germany, the scope of the Constitutional Court's review of constitutionality includes unconstitutional rules regardless of whether they are related to specific cases (Fan, 2005). According to Article 97 Section 1 of the Basic Law, the judicature legislation is also limited. Thus, as assistants of the legislature, German courts can perfect the current legal order but cannot change or decide it. Famous German jurist Harry Westermann provides wisdom on this point: "essentially, judicature is the valuable application of law, but not independent judgment by judges.” (Westermann, 1955). While this is not a problem in the common law system, according to the view of Posner in The Problems of Jurisprudence, common law refers to the law created by judges, who are themselves legislators. Such a view provides the historical evidence for judges to cross the boundary of power separation.

Social rationality as a reason for dismissal refers to the spaces left by legislators. Such spaces belong neither to the situation presented in 1(a), i.e., the thoughtful interpretation and application of the law in line with a legislator's original intention, nor to that presented in 1(c), i.e., contra legem, but to that presented in 1(b), i.e., the requirement of continuing construction or supplementation. The doctrinal premise and basis of such construction or supplementation have been adequate thus far. One point requires clarification: while in a civil law system the judges make judgments to address legislative spaces and loopholes, they treat this process as the discovery of law or an "objective" explanation and deny that they are making active decisions on legislative features. In the introduction of the first volume of his book Munich Civil Code Comment, Professor Säcker writes that if the legislative space is recognized, it is necessary to express where the standard of continuing construction or supplementation for such a space comes from. In other words, how to conduct the continuing construction and supplementation should specifically be discussed. A standard should be set for such construction, and an appropriate tool should be determined to establish that standard.

\section{2) The Tools Used by Judges}

a) Logical Argumentation

When continuingly constructing or supplementing specific dismissal reasons in line with social rationality, judges should not consider a situation based on analogy. Article 103 Section 2 of the Basic Law forbids the application of analogy in criminal law. There are two well-known reasons for this: there is no penalty without a

\footnotetext{
${ }^{16}$ Art.20 Abs.3 GG hat deutlich den Respekt vor der demokratischen Staatsordnung dadurch ausgedrückt,dass die Rechtssprechung an Gesetz und Recht bzw. An die gesetzliche Wertentscheidung gebunden ist.
} 
law (nullapoena sine lege), and judgment favors the accused when doubts of his guilt remain (in dubio pro reo). In the fields of public and criminal law, objective hermeneutics help eliminate normative legislation purposes and breach the prohibition of analogy in criminal law stipulated by a constitution. Therefore, they have encountered much criticism, and are only praised in private law such as civil law. In private law, while the practice of analogy prohibition leads to the refusal of a referee, the judge cannot refuse a referee solely because there is no legal basis. The necessity and urgency of a referee prevail over the criticism of legislation and the influence of the transiency of a court's decision. Judges must use the "prohibit denial of referee" (Rechtsverweigerungsverbot) principle consistently. If analogies such as analogies of rules and regulations (Gesetzesanalogie) and of law (Rechtsanalogie) were permitted, then the space or loophole in a law would be eliminated and the chance that a judge would provide continuing construction or supplementation would be doubtful. If there were no space for analogy, other methods would be required. In terms of rule and regulation analogies, there is no situation within the scope of our topic where laws and rules with different factual premises could simultaneously apply social rationality as a dismissal reason. In other words, the undecided interest status in question (i.e., the limitation of social rationality as a dismissal reason) has no similar existing interest state. Further, this interest state has already been regulated by law. The aforementioned Articles 138 and 242 cannot solve the problem of limitation, and even comprise a principle of general character that entails continuing construction. In terms of law analogies, this principle deduces one kind of basic idea from relevant theories on dismissal protection, the Enterprise Constitution and civil law to determine the limits of social rationality as a dismissal reason. In the contractual relationship, an equivalent and fair exchange between parties is more often than not clearly seen. However, it is difficult to deduce a complete specific method related to the limits of social rationality as a reason for dismissal by an advantageous party from the Civil Code. An enterprise's constitution regulates only some non-social-rationality problems that result from a breach of the rules set for decision power, and it is difficult to deduce the limits of social rationality as a dismissal reason. Dismissal protection laws refer only to the legislative technical concept of social rationality. Analogizing a law involves a value assessment based on the purpose of a regulation, and refers not to the assessment made by a judge himself, but either an assessment of the inner value systems of relevant laws or a kind of comparison. That is, if one fact could be applied according to the value standards of the norms recognized by a judge, then the other fact could be applied in the same way. However, we fail to deduce such a specific limit, and once again must turn back to the concept of social rationality left to us by legislators. If we deviate slightly from the objective scope in which the inner value systems of relevant laws could be assessed and compared, we discover an outstanding voluntarism characterizing the practice of analogizing laws. However, such a subjective assessment is likely to suffer another kind of question, i.e., why are the different characteristics of one factual action treated without distinction, yet similar factual actions are treated unequally? Several cases from the German Constitution Court and Civil Division of the Federal Supreme Court deal with these kinds of suits ${ }^{17}$.

According to a conservative mindset, we deduce that analogies cannot resolve the problems faced here. For that matter, neither can special forms of analogy, including a maiore ad minus and a minore ad maius, neither of which reveal the limits of social rationality as a dismissal reason. We have no limit smaller than this to help us deduce a maiore ad minus, and no bigger limit to help us deduce minore ad maius. For instance, in a special dismissal, an instant dismissal could be made for serious reasons. However, this does not account for the justification of a dismissal with advance notice. Because the dismissal reason categories are not embodied here, they may be inconsistent with social rationality. Further, they may be limited by the Dismissal Protection Statute, and therefore considered not in line with social rationality despite the advance-notice time limit.

Although special and non-special dismissals can be distinguished by their bearableness, the establishment of an unbearable and serious reason does not mean that a general dismissal with advance notice complies with regulations. A serious reason corresponds with social rationality, but not with advance notice. Therefore, the use of a minore ad maius reasoning alone is unconvincing.

Some scholars have proposed similar methods besides analogy to solve this problem, such as the focal point argument (argumentum a fortiori), counterevidence (argumentum e contrario, expression minus, argumentum $e$ silentio), alternate exclusion (exclusion alterius) and expansion/limitation interpretation. We support Coing Helmut's claim that it is inevitable for one to be deeply concerned about these supplementary means. According to his logic, no standard can come from using the analogy method, negative conclusion or expansion/limitation interpretation. On the contrary, we must research legal provisions to confirm our logical comparisons and decide

${ }^{17}$ BVerfGE72, 141; BVerfGE84, 133; BVerfGE1, 14; BGHZ112, 163. 
which method is better. The counterevidence method only works when the legislator has clearly thought about a legal loophole but remained silent on it. However, this seems not to be the case here, as it is not a loophole with intangible boundaries but a loophole of general terms. While Jhering questions the adoption of this concept and using logic to solve problems (Coing, 1993: Kapital 6-2.). The expansion/limitation interpretation cannot offer any help in this case. If legal science research were conducted only by logic, it would limit the evaluations of scholars and judges alike. The substantiality of law would struggle for enough attention and may even disappear. In his famous book entitled Common Law, Oliver Wendell Holmes denies the decisive role of logic in legal life: "The life of the law has not been logic: it has been experience. The felt necessities of the time, the prevalent moral and political theories, institutions of public policy, avowed or unconscious, even prejudices which judges share with their fellowmen, have had a good deal more to do than the syllogism in determining the rules by which men should be governed. The law embodies the story of a nation's development through many centuries, and it cannot be dealt with as if it contained only the axioms and corollaries of a book of mathematics." (Holmes, 2011: p. 5). Of course, Germany is a country in which statute law dominates, and judge-made laws are obviously inconsistent with the historical cost and advantages of a code system. However, we can neither hide from the logical system of concept law, nor ignore the legal realities, loopholes and sociality mentioned by Jhering. The Radbruchsche formula questions the use of positivism to adjust laws. According to German judicial habit, if we did not adopt the precedent doctrine and instead considered the formal legal source of stare dicisis, this paper would have to rely on the origin of legislation. Indeed, judges can consider and use the stare dicisis. There is no specific case of continuing law construction, which attempts to offer a standard similar to stare dicisis, i.e., a testing system that is more specific than the social rationality defined by legislators. Further, this seeks a standard that accounts for both the scope of legislative sources and a given range provided by legislators. Within this range is a connection between case corroboration and traditional civil law and the collaboration of cases and rules arising from precedents. While all of these aspects focus on systematic rational thinking, they also emphasize experiential thinking. Each has positive and negative points, both of which are very valuable for comparative law. However, because we focus on German law, our discussion does not take this specific direction, and we still require a context-definite system of social rationality to fill in legal spaces or loopholes. Therefore, the question persists. Although the concepts of law and logical deduction play very important roles in a civil law system, logical deduction itself cannot completely fill the legislative spaces intentionally left to judges. A specific system for verifying social rationality cannot be established, and scholars and judges must evaluate the value of its benefits. While we remain at the front door in terms of closing legal loopholes, judges could determine specific types of social rationality according to each case and the proportionality principle (Preis, 1987: S. $33 \mathrm{ff})$.

b) Case Groups of Dismissal Reasons

- The Connotations of Dismissal Reason Cases

As the social rationality of each dismissal is based on a specific reason, the German Federal Labor Court divided the types (Typisierung) of dismissal reason connotations according to legal precedents to clearly determine the "important reasons" given for special dismissals (Article 626 Section 1 of the Civil Code) ${ }^{18}$. This division is based on employee and enterprise relevance, work capacity and trust. The general dismissal reasons stipulated by the Dismissal Protection Statute in the first sentence of Article 1 Section 1 are also divided correspondingly, i.e., dismissal reasons initiated by behavior (trust domain), personnel (work capacity domain)and enterprise (enterprise relevance domain) (Erman-Hanau, 1993: Rn. 45).

However, this division does not represent the difference between special and general dismissals in practice; rather, it is a badge (Verdeutlichungsskalar) made via case groups of dismissal reason types. In German judicial practice, special dismissals made by enterprises for economic reasons (such as bankruptcy) are usually not established (KR-Hillerbrecht, 2007: §262 BGB, Rn. 87, 120 ff.; Münch.-Komm.-Schwerdtner, 1998: §626 BGB, Rn. $127 \mathrm{ff}$.). In principle, the risks (such as bankruptcy) to enterprises cannot be borne by employees through "special dismissal", but should be dealt with using a general dismissal method (urgententerprise reasons). Thus, the boundary between special and general dismissal is determined by the principle of unbearableness (Unzumutbarkeit). In judicial practice, the problem is not how to distinguish special from general dismissal, but how to distinguish the contemporary appearance of a dismissal reason. For example, consider cases in which two or three reasons appear simultaneously (e.g., a sick and incapable employee who is also professionally incompetent

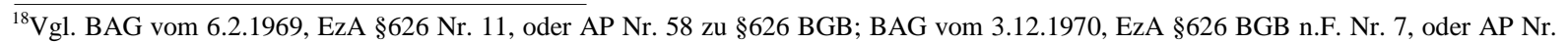
60 zu §626 BGB; BAG vom 28.9.1972, AP Nr. 2 zu §134 BGB; BAG vom 26.5.1977, EzA §611 BGB.
} 
and has an extremely poor job rating represents the effectiveness of an enterprise's operation). Such a situation would require further distinguishing of the judicial practice cases or types. German legal precedents are inclined to search for primary and secondary interference sources (primäre und sekundäre "Störquellen”). To address this "mixed composition of facts" (Mischtatbestände), German Professor Manfred Löwisch provides a directivestandard to distinguish interference sources according to the spheretheory (Sphärentheorie) ${ }^{19}$. However, if none of the many kinds of dismissal reasons in line with Article 1 of the Dismissal Protection Actis mainly affecting the survival of a work relationship (i.e., there are no important interference sources), it cannot be considereda mixed composition of facts.

In addition to the types of dismissal reasons, German legal precedents and theories have developed three types of typical and concrete precedents (Kataloge typischer Sachverhalte) to probe into social rationalityas a dismissal reason (KR-Becker, 2007: §1 KSchG, Rn. 193 ff., 239 ff., 315 ff.; Hueck/v. Hoyningen-Huene, 1992: S. 187 f., 306 f., 413 f.; Münch.-Komm.-Schwerdtner, 1998: Vorbemerkung zu §620-628 BGB, Rn. 231 ff., 258 ff., 273 ff., §626 BGB, Rn. 57 ff.; Herschel-Löwisch, 1984: §1 KSchG, Rn. 94 ff., 140 ff., 195 ff.; Löwisch/Spinner/ Wertheimer, 2013; Knorr/Bichlmeier/Kremhelmer, 1986: S. 289 ff.; KR-Hillebrecht, 2007: §626 BGB, Rn. 299 ff.; Palandt-Putzo, 2002: §626 BGB, Anm. 5).

However, these cases only have reference value when dealing with the same or similar compositions of facts and law applications in concrete cases. A social rationality evaluation is conducted to decide the "urgent enterprise need" in the dismissal reasons of an enterprise. However, these individual circumstances only work in concrete cases and not in principle when attempting to establish a standard of types or definite system. Therefore, German judges must seek other methods according to their tradition.

- The Essence and Function of a Case Group

The efforts to establish typologies of typical dismissal reasons and legal precedents have demonstrated a struggle to balance contradictions in specific types of justice. However, such efforts are connected with the security of law. The specific justice connected to built-in legal security holds great meaning in practice. For instance, when it comes to the dismissal reasons related to the physical abilities of personnel, a balanced benefit may place more of an emphasis on legal security and specific justice. When solving problems, judges frequently carry out an abstract classification of life facts within the legislative spatial scope, which differs along with typical and symbolic legal precedents. Bernd Rüthers observes that a typology of dismissal reasons cannot determine unification from diversity the way natural science does. Thus, such measures remain above the surface, and the essence of things awaits unearthing. However, the essence of things is actually the consensus of the opinio juris (legal conviction) that participants share (Rüthers, 2002: Rn. 920). As the conclusion of social science, an opinio juris often comprises many aspects, including content (Inhaltsirrtum), characteristic (Eigenschaftsirrtum) and explanation (Erklärungsirrtum) mistakes. The three "Ws" (what, where and who) that Ruethers provides offer some clarity; the author asked, "What is the essence of the things?" (what), "Where is it from?" (where) and "Who has the right to define the essence?” (who). According to Rüthers' conclusions, although they follow related facts, the relevance and natural science principles in the scope adjusted by law represent the tasks set by any legislation and legal application. Facts and conditions that must be determined in advance are not equal to the essence of things. In the same way, because we cannot neglect these facts and conditions to carry out doctrine-like legislation and legal applications, strange stipulations such as "planting bananas at the North Pole" cannot be made (Rüethers, 2002: Rn. 921.). Now that the essence of things is actually a consensus of the legal convictions that participants share, it cannot serve as the legal source that Rüthers envisions (Rüethers, 2002: Rn. 922f.). Rüthers is accurate in his conclusion that demonstration through the essence of facts and concrete order does not pertain to legal application; in fact, the essence of facts is not a legal origin, but the source and pronoun for the pursuit of legal policies.

Case types, typical law finding (typologische Rechtsfindung), the concept of the essence of things and so on represent the limitless measures a judge could take when creating a law. However, Rüthers doubts that seeking rules or norms only from these areas provides enough demonstration, but rather often serves the aims of legal policies (Rüethers, 2002: Rn. 935 f.). In this paper, demonstrations are not provided merely based on the aforementioned foundations.

c) The Principle of Proportionality

\footnotetext{
${ }^{19}$ Dabei richtet sich die Abgrenzung (nach der Sphärentheorie) bei sogenannten Mischtatbeständen danach, aus welchem der im Gesetz genannten Bereiche die sich auf den Bestanddes Arbeitsverhältnisses nachteilig auswirkende Störung kommt. Vgl. BAG vom 21.11.1985, D-Blatt “Kündigungsschutz: Entsch. 270” mit Anm. von Manfred Löwisch.
} 
The most thorough elaboration on the proportionality principle first appeared in the research of Germen jurists Ruprecht Kraus (Kraus, 1995: S. 18) and Peter Lerche (Lerche, 1961), and multiple German legal precedents have since involved its connotation. The function of the proportionality principle is to manifest balanced (i.e., legal) justice by balancing goals and means (Dornbusch/Fischermeier/Löwisch-Spelge, 2013: Art. 20, Rn. 18). This paper holds that the principle originated from Solon the Athenian at the earliest (Solon 640-561 v. Chr.). Solon heavily valued the idea of limits and excess; the key point of his philosophy could be expressed briefly as "do not be excessive". He takes justice as the aim and limits as the boundaries of social order, making him a good example to legislators of later ages (Wolf, 1953: S. 464). Aristotle (Aristoteles 384-322 v. Chr.) makes similar statements in terms of content structure. He thinks that justice lies in the middle part of possibility to breach the proportion: "Since the middle part is to be proportional, the justice is the proportion or ratio match." (Arisoteles, 1956). If we analyze its connotation, main points and origin, this principle could be included in thoughts on justice. Justice is certainly a very subjective concept, and one that is clearly elaborated by Hans Kelsen in What is Justice? However, almost all of the principles are relevant to justice thoughts. If we were to ascribe a proportionality principle to a justice thought, they would have to connect in both function and connotation. Justice is the basic value of common life. While it represents the right of an individual to a national and communal life, it also represents limitations and obligations (Metzner, 1970: S. 116; Wolf, 1953: S.P. 454). Thus, justice seeks a kind of proper and equal treatment of the members of a social community to prevent dictatorship and the abuse of rights. According to Hart, "justice is customarily considered to maintain or rebuild the balance." ${ }^{20}$ The ratio of balance, legality and deliberation not only involves relationships between equal parties, but also fits for non-equal parties (such as citizens and nations). Therefore, in their function and connotation, justice thoughts consider the proportionality principle and adjust the relationships between aims and methods to prevent excessive harm from befalling the balance of interests and values.

The functions of the proportionality principle are manifested in many legal fields. Balance and protection are particularly developed when legally defined provisions and spaces left by legislators are involved. Determining the departmental laws to which these functions specifically apply requires an examination of the academic and judicature fields. From the end of the 18th century until World War II, jurisprudential circles used the proportionality principle in the Police Law and justifiable defense in the Criminal Law ${ }^{21}$. Further, in explaining civil law questions, such as those related to good faith in the Obligation Law ${ }^{22}$, one legal precedent involves the proportionality principle (equal to the proportionality principle in a narrow sense) to explain the violation of good customs: "if the growth of the opposite party's disadvantage factors and its pursued values are radically unproportionate, the means used (by one's own side for this goal)is the violation of good customs."23 After World War II, academic circles introduced this principle into many other fields, mainly the public law fields such as administrative, criminal, criminal procedure and international law. However, the federal Labor Law precedent in $1971^{24}$ introduced it into the Labor Strike Law. In a legal precedent comment made in 1968 (Nipperdey, 1968; Säcker, 1972: S. 287.), Professors Hans-Carl Nipperdey and Franz-Jürgen Säcker, introduced "the proportionality principle" and "ultimatum principle” (Ultima-ratio-Prinzips) into the Labor Law (Bertelsmann, 1979: S. 164 ff.; Brox/Rüthers, 1982: Rn. 163 ff., 192 ff.; Joachim, 1973: S. 289.; Löwisch, 1971: S. 319.; Müller, 1972: S. 273.; Müller, 1980: S. 1694.; Nipperdey/Säcker, 1968: S. 155 ff.; Reuter, 1973: S. 284.; Rühers, 1972: S. 23; Säcker, 1972: S. 287; Seiter, 1979: S. 88 ff.; Seiter, 1975: S. 146 ff.; Zitscher, 1977: S. 65.). These principles were also later introduced into the Enterprise Constitution (known as the Enterprise Organization Law) and Dismissal Protection Statute. From World War II until now, the proportionality principle has not only been used by the Supreme and Senior Courts as an important principle, but has also functioned akin to basic rights in terms of status. The principle has not been manifested very clearly in civil law precedents ${ }^{25}$. However, similar to the principle, the Civil Courtyard repeated the thoughts of "protection in the utmost possible degree" in terms of damage compensation, and arrived at decisions on third-party torts in operating a professional enterprise on the basis of German Civil Law Article 823 Section 1and the balance problem of damage compensation caused by such torts $^{26}$. Criminal courtyards have often used the principle in penalty measurement as the principle for a

\footnotetext{
${ }^{20}$ See: H.L.A. Hart (UK): The Concept of Law, Oxford Uni Press, translated by Zhang Wenxian, Zheng Chengliang, Du Jingyi, Song Jinna, China Great Encyclopedia Press, Chinese version, p. 157.

${ }^{21}$ RGst 69, 308 (310, 312)/71, 133/72, 57/66, 1.

${ }^{22}$ RGZ 76, 150f./61, 133/85, 137.

${ }^{23}$ RGZ 104, 330/71, 108.

${ }^{24}$ Vgl. BAG vom 21.4.1971, GS 1/68-E 23, S. 292.

${ }^{25}$ BGHZ8, 142 (zur freien Entfaltung des Gewerbebetriebes), BGH in BB 1954, 457/BGHZ in GRUR1967, 430 f. (zu Art.1. UWG,).

${ }^{26}$ BGHZ8, 142/24, 200/45, 307.
} 
country under the rule of law ${ }^{27}$. The principle is also used in the Social Insurance Law, and its great significance has been further revealed in Constitutional Court precedents ${ }^{28}$.

The proportionality principle is not a purely legal thought or set of ethics, but one that manifests some kind of justice. Whereas both legal thought and ethics are subjective, the principle is objectively instrumental in itself. However, if judges were not able to achieve consensus on one kind of thought and natural science evidence was not able to objectively confirm these thoughts and ethics, judges would be doubted in their creation of laws. While the proportionality principle carries a certain objectivity, it is accepted by the Supreme Court and Constitutional Court and theoretical circles as a verification of social rationality. Because legislation has its space here, there is no need to worry about the danger introduced by an unlimited use of the principle. The application of one principle observes the general rule of "legislation privilege" in the judicial practice, and the abuse of principles can make legislation meaningless in judicial life. The remaining problem now is how to complete the continuing construction specifically with the help of the proportionality principle.

\section{A Definite System for Judges' Continuing Construction and Supplementation of Legislative Space or Loopholes}

Determining a solution mechanism entails the clarification of key questions. Here, an obvious question is how to establish the relationship between the goals and means and consider the benefits concealed within. The legal application scope of the proportionality principle is out of the question according to the first sentence of Article 1 Section 2 of the Dismissal Protection Statute. As such, whether the structure of the principle can be applied to all kinds of dismissal reasons or act as a specific structural application for the dismissal reasons initiated by enterprises remain problematic questions. A legitimate definite system must be "specifically" demonstrated and designed.

\subsection{Conditions in Advance: The Positioning of Time, Place and Object}

As a tool, the structure of the proportionality principle takes conditional effect in legitimate definitions of the dismissal reasons of enterprises. First, we must define the relevant time, place and object so that the proportionality principle can be applied specifically to a structure according to the first sentence of Article 1 Section 2 of the Dismissal Protection Statute.

\subsubsection{Definite Object}

A definite system of the proportionality principle must be related to a particular object. According to the essence of the legal labor relationship, this definite system is protective. Its objects, i.e., targets, are full-time (Vollbeschäftigte Arbeitnehmer) (Wank, 1988) ${ }^{29}$, part-time (Teilzeitbeschäftigte) ${ }^{30}$ and leading (Leitende Angestellte) (Martens,1982) ${ }^{31}$ employees.

However, this definite system does not include a person's legal representatives (gesetzliche Vertreter) ac-

\footnotetext{
${ }^{27}$ BGHst16, 300, 23, 192, 24, 132.

${ }^{28}$ BverfGE 7, 377 ff., BverfGE 8, 80, VerfRspr. 2/7(8, 15), BVerfGE 6, 439/17, 117/19, 342/349/20, 49/21, 220-223/34, 384/35, 320/34, 266-267/3; BVerfGE 17, 280/17, 306/19, 342/21, 173/22, 26/30, 316-317/34, 266-267.

${ }^{29}$ Nach ständiger Rechtsprechung ist die Arbeitnehmereigenschaft von der aufgrund privatrechtlicher Verträge oder eines ihm gleichgestellten Rechts unbedingten wirtschaftlichen Abhängigkeit (Berger/Delhey/Alfmeier, NZA 1991, 257; Hilger, RdA 1989, 51ff.; v. HoyningenHuene, BB 1987, 1730 ff.; zu Abweichenden Auffassungen vgl. Adomeit, Gesellschaftsrechtliche Elemente im Arbeitsverhältnis, 1986.). Entscheidend ist die Weisungsgebundenheit nach Ort und Zeit der Arbeitsleistung und die fachliche Weisungsgebundenheit sowie das fehlende Unternehmerrisiko (Hueck/v. Hoyningen-Huene, §1 KSchG. Rn. 25; v. Hoyningen-Huene, BB 1987, 1730, 1732; Staudinger/Richardi, Vorbem. zu $§ 611$ ff. Rn. 174). Im Zweifelsfall ist Eigenschaft der Arbeitnehmer anhand der Umstände des Einzelfalls durch eine Gesamtwürdigung der Tätigkeit zu ermitteln (Söllner MK-BGB §611 Rn. 131 ff.).

${ }^{30}$ Die Teilzeitbeschäftigten sind auch Arbeitnehmer. Die Arbeitszeitbegrenzung in §23 Abs. 1 Satz 3 KSchG spielt ausserrhalb des betrieblichen Geltungsbereichs des KSchG keine Rolle (BAG vom 13.3.1987, NZA 1987, 629; DB 1983, 2473; Wank, ZIP 1986, 212.; SAE 1988, 71 mit insoweit ablehnender Anm. Adomeit; kritisch hierzu Hahn, DB 1988, 1015).

${ }^{31}$ Für leitende Angestellte, soweit sie zur selbständigen Einstellung oder Entlassung von Arbeitnehmern berechtigt sind (BGH 20.12.1961, AP Nr. 1 zu $\S 12$ KSchG; finden nach §14 Abs. 2 KSchG die Vorschriften des allgemeinen Kündigungsschutzes (Art.1-13 KSchG) mit Ausnahme des $\$ 3$ (Kündigungseinspruch beim Betriebsrat) Anwendung. So wirkt das Kontrollnetz auch für die leitenden Angestellten(Die Definition des leitenden Angestellten im BetrVG deckt sich nicht mit dem des KSchG, vgl. §14 Abs. 2 KSchG, §5 Abs. 3 Nr. 1 BetrVG, DB 1987, 179 = LAG Berlin vom 18.8.1986 LAGE §14 KSchG Nr. 1.) wie z.B. Geschäftsführer oder Betriebsleiter, die gem. §14 Abs. 2 KSchG als echte Arbeitnehmer (Zur Verbindung mit einer Organstellung nach Abs. 1, vgl. BAG vom 24.8.1972, AP Nr. 2 zu 611 BGB Gemischter Vertrag; dazu Hueck/v. Hoyningen-Huene, S. 424 Rn. 6 ff.) gelten, obwohl der Arbeitgeber nicht verpflichtet ist, seine Gründe für den Antrag der Arbeitsverhältnisauflösung auch nur zu nennen (Vgl. Gegenmeinung: Säcker, RdA 1976, 91, 98). Prokura allein wird nicht als Schutzobjekt angesehen, falls die leitende Position fehlt.
} 
cording to Article 14 Section 1 of the Dismissal Protection Statute; directors of joint-stock companies (Vorstandsmitglieder einer Aktiengesellschaft) according to Article 78 Section 1 of the Law on Shares (AtienG), directors according to Article 24 Section 1 of the Law on Economic Partnership (GenG); community directors according to Article 26 Section 2 of the Civil Code; foundation directors according to Article 86 (and Article 26 Section 2) of the Civil Code (BGB); "non-independent directors" according to Article 35 Section 1 of the Law on the Limited Liability Company (ein "abhängiger" Geschäftsführer) or "non-independent directors" of the limited liability companies who are also the unlimited liability shareholders and directors of a limited partnership (GmbH \& Co. KG) according to Article 170 of the Commercial Code (and Article 35 Section 1 of the Law on the Limited Liability Company) (Hueck, 1991: §37 II 2.). Given the independent nature of personnel, a shareholder, an organizational member or a partner ${ }^{32}$ cannot be an object of the principle's protective system beyond acting as the third person opposite the legal person. Officials and family members are also excluded because they do not work according to contracts. In The Defected Laboring Contract (der fehlerhafte Arbeitsvertrag), Kässer raises the issue of employees in the de facto labor relationship (Kässer, 1979: S. 54 f.). Due to their relaxed conditions, such employees cannot be covered by general protection laws against firing (KR-Becker, §1 KSchG Rn. 21). Personnel who accept training are also not included. (Indeed, dismissal within a certain period is usually forbidden in the training relationship.) Finally, day laborers in broadcasting stations (Rundfunkanstalten) are also excluded ${ }^{33}$.

\subsubsection{Restriction of Place and Time}

The object of protection lies with enterprises according to the Dismissal Protection Statute. The definition of an enterprise used in Article 1 of the Dismissal Protection Lawis consistent with that used in the Enterprise Constitution (BetrVG) (Herschel-Löwisch, 1984: Rn. 173; KR-Becker, 2007: Rn. 80; Löwisch/Spinner/Wertheimer, 2013). Enterprises as such must employ not less than 10 employees $^{34}$ (not including those being trained according to Article 23 Paragraph 1 Sentence 2 of the Dismissal Protection Law). Whether employees belong to a particular enterprise does not always depend on the standard in place ${ }^{35}$. This definite system is timely, meaning it meets the requirement that the employees' labor relationship must last for 6 continuous months in one enterprise (Betrieboder Unternehmen). If one intentionally evades the related laws to shorten his working period to fewer than 6 months and void the Dismissal Protection Law, the conditions he attempts to prevent shall be viewed as already achieved according to Article 162 of the Civil Code.

\subsection{Purpose Positioning for a Definite System}

The outer reasons for a dismissal by an employer reflect the internal motive of the dismissal. The reasons and motive are not definitely the same. While different motives can be derived from the same demand, different demands can in turn produce the same motive. The German scholar Zitscher identifies the problem with this observation. He considers that a purpose (which we consider a demand and motive) is the anticipated attitude of the actor (innere Erwartungshaltungen des Handelnden) (Zitscher, 1980: S. 1285, r. Sp., 1289, r. Sp., 1290) that only the actor understands (Zitscher, 1980, S. 1289, r. Sp.). Due to the diversity of the applied means (which we consider an external reason or action), people cannot confirm the indicated purpose according to the means themselves (Zitscher, 1980: S. 1290, 1. Sp.). Zitscher implies that the real demand for dismissal (die echten Kündigungsbedürfnisse) and the internal motive (die inneren Motive) are difficult to confirm (unbestimmbar), and that this raises people's suspicions. When a purpose cannot be confirmed, i.e., when a legal reason is used to pursue an illegal motive or precondition, is the purpose maintained? This question seems to reveal defects in the instrumental character of the proportionality principle (der Grundsatz der Verhältnismässigkeit). Adomeit from the University of Berlin is also aware of this problem. He formulated his plan (which may be a general parlance) due to the demand for a safe nature of law and consideration of actual practices. For Adomeit, the external constitution of facts (äusserer Tatbestand) is more important than the hidden firing purpose. His objective choice

\footnotetext{
${ }^{32}$ BAG vom 16.2.1983, AP Nr. 8 zu § 2 AngKSchG mit Anm. Brackmann; KR-Becker §1 KSchG Rn. 32.

${ }^{33}$ Berger-Delhey/Alfmeier, NZA 1991, 257 ff; BAG vom 13.1.1983, AP Nr. 42 zu §611 BGB Abhängigkeit zum arbeitsrechtlichen Status der Rundfunkamitarbeiter; BAG EzA §611 BGB Arbeitnehmerbegriff Nr. 16, 17, 18, 21, 22 und 27, BVerfG vom 13.1.1982, EzA Art. 5 GG Nr. 9; Rüthers, DB 1982, 1869; Wank, RdA 1982, 363.

${ }^{34}$ Der allgemeine Kündigungsschutz nach dem KSChG gilt nur für Betriebe und Verwaltungen mit mehr als 10 Arbeitnehmern (§23 Abs. 1 Satz 2 KSchG). Früher: der gilt in diesem Fall mit mehr als 6 Arbeitnehmern.

${ }^{35}$ Vgl. BSG USK 72115.
} 
shows that people cannot avoid the effects of hidden dismissal reasons. Even if these hidden dismissal reasons were not legitimate, people could only take measures against activities to evade laws and prevent themselves from being harmed by illegal "cleverness". However, the problem of pursuing the real legal purpose of dismissalhas yet to be resolved.

Holly also attempts to resolve this problem, observing that employers should initially put forward a firing reason that could be accepted principally and that must have at least one proven active purpose. Although Holly does not totally resolve the problem, he raises the important observation that a firing reason should come out of an active purpose. We examine this problem from two angles. The first is whether people are able to look for a concrete and primary firing demand that is objectively functional and subjectively pursued. As Adomeit observes, the internal motive is not important. Motives that are "spoken out" (which are equal to the reasons for firing) are in fact concrete reflections of the primary firing demand. As long as the reason for firing is caused by one demand that could comply with a related legal purpose, (i.e., the reason accords with a related legal purpose), no problem should be presented. We arrive back at Adomeit's conclusion that improvement can only come from striving for a reasonable purpose. Second, whether firing reasons are established in laws should comply with social rationality, and render a concrete definition of value to clearly define the instrumental character of the proportionality principle. Research on this point continues to be necessary. The key issue is that a firing must have a proven purpose in a dismissal procedure that can be accepted according to the relevant laws and facts (Preis, 1987: S. 311.).

\subsection{Positioning of Effectiveness for a Definite System}

The Federal Labor Court of Germany introduced the principle of proportionality applied in the area of public law (Verhältnismässigkeit ${ }^{36}$ ) into its Labor Strike Law $^{37}$ and Enterprise Constitution ${ }^{38}$ (vgl. auch Fitting/Auffarth/Kaiser/Heither, 1987: §40 Rn. 8, 30). The auxiliary (Untergrundsätze) or partiality (Teilgrundsätze) principles of effectiveness, necessity and proportionality have been applied inits numerous prejudications. According to the partiality principle of effectiveness, achieving certain goals requires that only those means that could achieve the goals in principle be used. The principle cares only about whether these kinds of means are able to realize a set purpose, and does not care whether any problem persists in terms of the quality of the means or whether it would introduce any other favorable or unfavorable factors (Holly, 1989: S. 56).

\subsection{Positioning of Means for a Definite System}

\subsubsection{Hubmann's Opinion}

Hubmann (Hubmann, 1955: S. 85 f.) raises the principle of best protection means in the area of civil law. He observes that the damage value of smaller means is restricted by that of larger means. People must choose the best or least harmful means to protect their benefits. In particular, the chosen means must not prohibit achievement any further, meaning that the set damage should not exceed the goal to achieve (Hubmann, 1955: S. 127). This principle coincides with the necessity and proportionality principles. It could apply to dismissals by enterprises, as dismissals harm the lives of employees. Therefore, the auxiliary necessity principle mainly determines whether there are disposable intervening means that have the same effect but are less harmful to the legal positions of other people (eingleichwirksames, aber in fremde Rechtspositionenweniger starkeingreifendes Mittelzur Verfügung stand) (Blomeyer 1979: S. 17; Löwisch, 1971: S. 319, 321 unter 1.2.; Seiter, 1975: S. 154.; Zöllner, 1963: S. 351). Measures that do not comply with the effectiveness (Ungeeignetkeit) are usually not in accor-

\footnotetext{
${ }^{36}$ According to the German, this principle was supposed to be translated into "the principle of propriety", but this principle includes the principle of effectiveness, the principle of necessity and the principle of proportionality. Its essential part actually is the principle of proportionality. In German, the principle of proportionality is written as Proportionalitätsprinzip or der Grundsatz der Proportionalität. Most importantly, in German, the principle of propriety in a narrow sences is often written as Verhältnismässigkeit i.e. S., it often refers to the principle of proportionality which is within the principle of propriety in a broad sense.) In order to highlight the main context of this principle, I will use the principle of proportionality in the following.

${ }^{37}$ Vgl. bereits BAG vom 21.4.1971, a.a.O.; vom 10.6.1980-1 AZR 168/79-BB Beil.4/1980, 2, 10 f. unter B.I; vom 10.6.1980-AZR 822/79BB Beil.4/1980, 13, 21 unter B.I.; vom 12.9.1984-1 AZR 342/83-NZA 1984, 393, 398 unter B.II.2.b); vom 12.3.1985-1 AZR 636/82-NZA 1985, 537, 538 unter II.2.b).AuchLöwisch, Arbeitskampf-und Schlichtungsrecht, 1997.

${ }^{38}$ Vgl. BAG vom 9.10.1973-1 ABR 6/73-AP Nr. 4 zu §37 BetrVG 1972 unter III.1., Bl. 171; vom 27.9.1974-1 ABR 71/73-AP Nr. 18 zu §37 BetrVG 1972 unter III.4., Bl. 394; vom 8.10.1974-1 ABR 72/73-AP Nr. 7 zu §40 BetrVG 1972 unter III.4., 5. und 6., Bl. 26 ff.; vom 3.4.1979-6 ABR 70/76-DB 1979, 1800 unter 2.b) und c) jew.a.E.; vom 4.12.1986-GS 1/82-NZA 1987, 168, 175 unter C.II.5.; vom 17.3.1987-3 AZR 64/84-NZA 1987, 855, 857 unter II.1.
} 
dance with the necessity principle. While it may exceed the scope of the nature of necessity, it may not achieve the aim; therefore, some Germany scholars consider it not an object of inspection for the nature of necessity but part of the necessity principle (Blomeyer, 1979: S. 19.; Reuter, 1975: S. 275, 282; Metzner, 1970: S. 70.). On the issue of choosing less harmful means, we accept the following situations. One measure may introduce larger damages to the parties, but if the purpose pursued by this measure offers such a result, it is permitted during the examination of the nature of necessity. In his doctoral dissertation entitled "Prohibition of the Improper Proportion in Private Law," Metzner observes that the proportion relationship between means and aims can be measured only if the third propriety principle, i.e., the proportionality principle, is involved (Metzner, 1970: S. 69; Seiter, 1979: S. 154.). Holly pursues an application method for judicature and theory in his doctoral dissertation (Holly, 1989: Fn. 324, S. 18 ff, insbesondere 21 ff. und 44 ff.), particularly in terms of regulating means and aims. He arranges the legal conditions he would pursue in order from the least strongest means to the strongest (Holly, 1989: S. 83-88). These include 1) normal variation dismissals with foretelling periods (ordentliche, fristgerechte Änderungskündigung) ${ }^{39}$; 2) special variation dismissals without any foretelling period (ausserordentliche, fristlose Änderungskündigung); 3) normal dismissals with foretelling periods and 4) special dismissals without any foretelling period (periodausserordentliche, fristlose Beendigungskündigung). He believes that if the purpose of a dismissal could be achieved through a normal variation dismissal with a foretelling period, it would be needless to use other dismissal forms that disobey the necessity principle.

\subsubsection{The Connotation of the Ultimatum Principle}

The German Federal Labor Court proposed the ultimatum principle in a very important judgment delivered on May 30, 1978. In this judgment, the Court held that regardless of whether a dismissal is general or special, only under the restriction of this ultimatum principle could it be considered in line with the necessity principle, i.e., as the means resulting in minimum damage. Aside from the means of dismissal, the specific dividing line of this principle is that if no other work possibility is presented, including jobs involving worse labor conditions than before, such a dismissal conforms with the ultimatum principle ${ }^{40}$. This is mentioned specifically in Löwisch's view on the role of the ultimatum principle in enterprises' reasons for dismissal. If due to a depression of the American economy the volumes of production of a German company declined drastically, the company could adopt a short-time labor system through negotiations with the Enterprise Council. However, if the Council were to refuse such a proposal, the company would dismiss employees. Here, we refer to the question of social rationality as a dismissal reason in the first sentence of Article 1 Section 2 of the Dismissal Protection Statute. The article mentions that if no urgent enterprise need is offered or the need contradicts the employee labor relationship, such a dismissal would be classified as a non-social-rationality dismissal. In a private company, employers dismiss employees for external economic reasons, especially in cases of slumping fee delegations, raw material and energy shortages and financing difficulties. In addition, some reasons relate to the enterprise itself, such as changes in its goals, the enforcement of rational acts and the introduction of new technology and methods. The same situation occurs in public enterprises (Betrieb des Öffentlichen Dienstes) due to the cancellation of production and impossibility of performance for external reasons or the requirement of leaner measures by an internal administration to lay off employees. However, a dissertational analysis of the law reveals that the urgent enterprise needs mentioned in the first sentence of Article 1 Section 2 of the Dismissal Protection Statute require sufficient reason when such dismissals occurred. Enterprise decisions are not equal to urgent enterprise needs (Löwisch, 2002: S. 346; Löwisch/Caspers/Klumpp, 2012). More importantly, enterprise decisions are unrestrained by the Dismissal Protection Statute because they are protected by the Enterprise Constitution. For instance, Article 2 Section 1 of the Basic Law protects the freedom of the economical development of an enterprise; Article 9 Section 1 of the Basic Law protects the independent association of an enterprise for economic purposes; Article 14 of the Basic Law protects the property of an enterprise for economic purposes, including the ownership of stock in a company, and Article 12 Section 1 of the Basic Law extends the freedom of work to the freedom of enterprise establishment and operation (including large enterprises) and to the freedom of contract signing (the contract freedom of employees and employers ${ }^{41}$ ). The work freedom of an employer is certainly restricted more stringently by the law. Therefore, judges cannot review the enterprise decisions in busi-

\footnotetext{
${ }^{39}$ Daneben gibt es noch die Änderungsvereinbarung, die Aususeung gesetzlich eingeräumter bzw. vertraglich vorbehaltener Leistungsbestimmungsrechte (Direktionsrecht, Widerrufsvorbehalt).

${ }^{40}$ Vgl. BAG vom 30.5.1978, AP Nr.70 zu §626BGB; Müench.-Schwerdtner,Vorbemerkung zu §§620-628 BGB Rn. 157 und §626 BGB Rn. 21.

${ }^{41}$ BVerfG vom 19.10.1983 - AP Nr.2 zu § 1 BetrAVG Unterstützungskassen = DB 1984,190, NJW 1984, 476.
} 
ness operations after the fact (Löwisch, 2002: S. 347; Löwisch/Caspers/Klumpp, 2012.). Maintaining employee benefits in enterprise decisions is not a task of the Dismissal Protection Statute, but the legislative task of the Enterprise Constitution (Article 111) in terms of the right to participate and decide. However, although judges do not review enterprise decisions, this does not mean that urgent enterprise needs can be met in Dismissal Protection Statute lawsuits whenever an enterprise owner provides such a reason. Once again, enterprise decisions are not equal to urgent enterprise needs.

Judges pay more attention to 1) whether inside or outside enterprise decisions have been already made and 2) whether such decisions make it necessary to carry out a firing inside the enterprise (the essence of the issue). If an entrepreneur invokes a long-term sales drop as a reason for dismissal, then a judge could examine whether a long-term sales drop did in fact take place, and the extent to which it affected the employee to be fired ${ }^{42}$. In one case decided by the German Federal Labor Court on April 30, 1987, the Court held that an apparent irrational "enterprise rationalization measure" (enterprise decision) cannot be viewed as an "urgent enterprise need" for dismissal. However, it represents an important stage for judges to verify "costsavings" (Kostenersparnis) in enterprise decisions. Preis and Löwisch offer different opinions on the subject (Rieble, 1996: Rn. 1008.) ${ }^{43}$. We find that judges must decide whether an enterprise decision could be viewed as an "urgent enterprise need" to satisfy the social reasonableness condition, which is set out in the first sentence of Article1 Section 2 of the Dismissa Protection Law. Judges are generally not required to examine the reasonableness of market-oriented "enterprise" decisions, only to focus on whether such "enterprise needs" have reached an appropriate degree of "urgency". This is where the ultimatum principle plays its role. Whether a dismissal caused by an enterprise was a last resort must be verified. If the dismissal was not inevitable, then it is not an "urgent" enterprise reason ${ }^{44}$. The second sentence of Article 2 Section 2 Part III of the current Social Code (SGB) emphasizes the bottom line of this principle. As long as an employee can be arranged within an enterprise or its affiliates, that employee's dismissal by the enterprise should be avoided. Cases ${ }^{45}$ decided by the Federal Court in the 1980s determined that entrepreneurs should not place employees into other enterprises (Emmerich/Habersack, 1998) ${ }^{46}$, as it would be in breach of those enterprises' independence. In the 1990s, the Federal Court held that aside from the aforementioned situations, employees could be placed into other enterprises only if another concerned enterprise claimed acceptance ofthe employee or aimed to fulfill its obligation. Such an employee would be placed and adjusted within the relevant enterprise's scope according to the scheme. Only in this way could the employee be placed into other enterprises ${ }^{47}$. As long as there are possibilities for work after continuing training (Fortbildung) or turned training (Umschulung), firings should not be administered (no use of ultimatum). The limitation also indicates that if an employee accepts a labor contract with conditional changes, no firing is allowed. The ultimatum principle even restricts entrepreneurs from dismissing employees who do not give up overtime or tentatively adopt short-term work systems.

\subsubsection{The Differences between the Necessity and Ultimatum Principles}

In terms of classification and function, the necessity principle differs from the ultimatum principle in that it leads to the examination of dismissal reasons ${ }^{48}$ and measures the necessity (Notwendigkeit) and weight (Gewichtigkeit) of dismissal reasons as the second proportion principle. As the last absolute boundary (das letzte absolute Grenznetz), the ultimatum principle not only excludes measures that would bring about unfavorable results, but also applies to special dismissals without any advance notice. Aside from these differences, the two principles also differ in their applicable scopes, emphases and results. However, these differences do not affect the establishment of a definite system. The ultimatum principle (Ultima-Ratio-Prinzip) could serve as a "bottom line” for supplementing the definite system in the applicable scope of the necessity principle. In addition, the ultimatum principle is usually not applied in favor of the necessity principle. Because their differences do not affect the logical reasoning of a definite system, there is no need to explore them any further.

\footnotetext{
${ }^{42}$ BB1989, 2190 = NZA 1990, 65 = EZA§1 KSchGBetriebsbedingte Kündigung Nr.63.

${ }^{43}$ Preis, NZA1995, 248; Löwisch, TK-KSchG, §1 KSchG, Rn. 259.

${ }^{44} \mathrm{BB}$ (Zeitschrift für Betriebsberater) 1980, 1103.

${ }^{45}$ Vgl.: BAG vom 22.05.1986.

${ }^{46}$ Das Recht der verbundenen Unternehmen sowie Konzernrecht, Vgl: §§15-19, §§291-328 AktG und.

${ }^{47}$ Vgl.: BAG vom 27.11.1991.

${ }^{48}$ Vgl. BAG vom 17.5.1984-2 AZR 3/83-NZA 1985, 91, 92 unter II.1.B) und vom 20.2.1984 AZR 633/82-NZA 1985, 286 f. unter I.3.nd 4.a).
} 


\subsubsection{Arrangement of the Optional Means}

The proportionality principle and Article 1 Section 1 of the Dismissal Protection Statute regulate the bottom line of unlimited dismissal by employers ${ }^{49}$. Employers conduct special dismissals only when they are unavoidable (ultima ratio) (Münch.-Komm.-Schwerdtner, 1998: Rn. 157 vor $\S 620$ BGB; KR-Wolf, 2007: Grunds. Rn. 280 ff.). In reference to the comments on legislation, judgments and doctrines, the legal means could be arranged from lightest to strongest as follows: 1) warning (Abmahnung) (Münch.-Komm.-Schwerdtner, 1989: Rn. 158 vor $\$ 620$ BGB; KR-Wolf: Grunds. Rn. 218-219. . $^{50}$, admonishing (Verwarnung) ${ }^{51}$, rebuking (Verweises) ${ }^{52}$ or penalty within the enterprise (Betriebsbusse) ${ }^{53}$; 2) transference of position in a manager's power and authority (Versetzungim Rahmen des Direktionsrechts) (KR-M. Wolf, 2007: Rn. 217 f.; Stahlhacke/Preis, 1991: Rn. 15); 3) modification of the contract (to be agreed upon) (einverständdliche Vertragsänderung); 4) normal altereddismissal (ordentliche Änderungskündigung) (Kempff, 1978: S 1400; Ratajczak, 1984); 5) special altereddismissal (ausserordentliche Änderungskündigung); 6) normal dismissal (ordentliche Kündigung) and 7) special dismissal (ausserordentliche Kündigung). The measures adopted by employers are restricted. Because they should not stray too far from the reasons for dismissal, employers should choose mild means or measures to achieve reasonable aims. The kinds of means an employer adopts depend on whether the employer chooses milder measures unconditionally ${ }^{54}$. According to judgments and doctrines, when employers have demands to dismiss for enterprise reasons, measures such as extending work (Arbeitsstreckung),which generally affects reserved (AufLager-Arbeiten) and short-time (Kurzarbeit) work; abolishing overtime work (Überstunden) and external working relationships (Leiharbeitsverhätnissen); shortening usual work times; establishing temporary (periodical) working relationships (Teilzeitarbeitsverhltänisse); cutting subsidies beyond the wages established by contracts (Krüzungaussertariflicher Zulagen); offering vacations ahead of schedule and ceasing applications by invitation can be adopted to prevent dismissals by enterprises. The measures typically adopted are analyzed as follows.

\section{1) Short-Time Labor}

Short-time labor is a special form of "extensive work" (spezielle Form der Arbeitsstreckung) ${ }^{55}$. It could be an effective and necessary means of preventing firings by enterprises (eingeeignetes und milderesMittel). However, during the implementation of a law, the power to introduce relatively mild short-time labor is not totally in the hands of employers. Such power is typically restricted by the enterprise's senate (Betriebrat) and established by its constitution (§87 Abs. 1 Nr. 3 BetrVG) ${ }^{56}$. An enterprise senate could either reject (Preis, 1987: S. 406.) or require $^{57}$ the introduction of short-time labor. If no enterprise senate exists, all of the employees who have related benefits due to the introduction of short-time labor must vote for it. However, employers are not forced to take on the responsibilities of the economic and technological risks caused by the introduction of short-time labor $^{58}$. Whether the introduction of short-time labor functions as a milder means of avoiding dismissals by enterprises is an issue that shall be examined by judges in Germany (richterliche Überprüfung) ${ }^{59}$.

\section{2) Abolition of Overtime Work}

The abolition of overtime work (Hillebrecht, 1985: 257, 260; Preis, S. 410) could be an effective and necessary mild measure of preventing dismissals by enterprises ${ }^{60}$. Employees who work overtime cannot be removed under real conditions. If the related overtime work cannot be abolished, the employers take on the burden of proof. The employers must clarify and prove (substantiertdarlegen und beweisenhaben) why the abolition of overtime work is impossible, and why the abolition of overtime work or external work relationships cannot be considered a milder means of preventing dismissals by the enterprise.

\footnotetext{
${ }^{49}$ Vgl. BAG, NJW 1982, 1062, 2687; ArbG Bocholt, DB 1982, S. 1938.

${ }^{50}$ Vgl. Becker-Schaffner, DB 1981 S. 1775 m.w. Nachw.; BAG, NJW 1982 S. 1062.

${ }^{51}$ Vgl. BAG vom 13.7.1962, AP Nr.1 zu § 242 BGB; Zur Anfechtung einer Verwarnung : BAG vom 22.2.1978, SAE 1978, 269.

${ }^{52}$ See the above footnotes.

${ }^{53}$ Vgl. BAG vom 5.12.1975, Rn. 190. zur Abgrenzung der Betriebsbussen zu Verwarnung: BAG vom 14.12.1966, AP Nr. 57 zu 59 BetrVG; BAG vom 30.1.1979, EzA Nr. 3 zu §87 BetrVG 1972Betriebsbussen.

${ }^{54}$ Vgl. NJW 1982, 2687; BAG, NJW 1979, 332.

${ }^{55}$ Vgl. Kurzarbeit und Überstunden sind eine spezielle Form der Arbeitsstreckung im weiteren Sinne. Die Arbeitsstreckung im engeren Sinne liegt vor, "wenn weder Überstunden abgebaut werden noch Kurzarbeit eingeführt wird, jedoch die Arbeitsmenge pro Mitarbeiter und Zeiteinheit herabgesetzt wird”. (Preis, S. 404 f.; Berkowsky, 1994, S. 47 Rn. 122, 123).

${ }^{56}$ Eine formlose Regelungsabrede zwischen Betriebsrat und Arbeitgeber über die Einführung von Kurzarbeit wahrt das Mitbestimmungsrecht des Betriebsrats nach §87 I Nr. 3 BetrVG.

${ }^{57}$ Vgl. BAG vom 4.3.1986, 1 ABR 15/84; NJW 1987, 1844; Gräbert, NZA 1986, 432, 412.

${ }^{58}$ Vgl. Dencke, ZfA 1985, 249.

${ }^{59}$ Vgl. Meinhold, BB 1988, 623; NJW 1987, 1844 = NZA 1986, 432.

${ }^{60}$ Zur Definition vgl. Berkowsky, a.a.O., S. 48 Rn. 127.
} 


\section{3) Other Measures}

Other measures include the cancellation of extra wages beyond contract salaries or subsidies agreed to by contract, the cancellation of additional awards (Gratifikationen) (e.g., Christmas bonuses) and subsidies and the transformation into temporary (periodical) work relationship measures ${ }^{61}$. Employers must check whether a work relationship could be kept temporary (periodical) before a dismissal occurs. According to the continuing spirit of judicial precedents in Germany ${ }^{62}$, employers can only dismiss an employee if they have adopted certain measures to prevent the dismissal, such as offering vacations ahead of schedule, signing temporary (periodical) working agreements and abolishing overtime work. Another measure involves the ceasing of applications (Einstellungsstop) (Wolter, 1980: S. 178.) received from young or personnel (Jugendoder Personalvertretung) representatives through invitation ${ }^{63}$.

\subsection{Positioning of Interest Equilibrium for a Definite System (Löwisch's Considerations)}

The proportionality principle examines the effectiveness of available means and then chooses the means (necessity) that are least harmful to employees' benefits and still achieve a set goal. It measures interests entirely to examine whether the goal interests addressed by the least harmful means are extremely higher than the value of the damage done to employees' basic rights to life and property (i.e., the proportionality principle in a narrow sense). Even if the means used are the least harmful to the affected employees, the goal interests must not be extremely higher than the value of damages done to the employees' basic rights to life and property (Jakobs, 1985: S. 97). As a last line of defense, the proportionality principle in a narrow sense is doubtlessly an interest measurement (Interessenabwägung) (Holly, 1989: S. 60 ff.). It is also a measurement adopted by Article 626 Section 1 of the Civil Code. In fact, examining the necessity principle reveals a consideration of interests, including how to choose the least damaging measure that could also achieve the goal. It also reveals a consideration of the proportionality principle in a narrow sense, which measures whether the goal interests introduced by the least damaging measure are proportionate to the damages caused by the measure. While interest consideration within the necessity principle measures the various means in a goal platform, the interest consideration of the final proportionality principle in a narrow sense measures interest on the basis of goals. In the legal culture or philosophy of Chinese laws, such a measurement has a corresponding philosophical or cultural principle (e.g., the principle of Zhongyong, translated into English as "gold mean"). Only after all of the relative interests have been measured or considered can the examination of the final principle be completed.

In addition to the aforementioned balance of interests, if more people must bedismissed than given other work, social selection (Sozialauswahl) (Dornbusch/Fischermeier/Löwisch-Kaiser, 2013: §1 KSchG, Rn. 116, 200, 201 ff; 194 ff, 198, 116, 199, 224 f, 229; §2 KSchG, Rn. 47, 52) is required according to Article 1 Section 3 of the Dismissal Protection Statute. The employees who do not belong to the social selection are allowed to leave. Even if it has been examined by the proportionality principle and the urgent business needs requirement has been met, such dismissal could be considered in line with social rationality.

However, this is not the case if the social rationality requirement is ignored. Social selection considers important elements (Löwisch, 2002: S. 352; Löwisch/Caspers/Klumpp, S. 2012) such as 1) the employee’s length of service (Die Dauer der Betriebszugehörigkeit), which could represent the employee's worth in the workplace; 2) the employee's age (Das Lebensalter des Arbeitnehmers), as older employee find it more difficult to adopt new jobs compared with young employees and also find it difficult to adapt to movement (Wohnungswechsel), and 3) the obligation of employee support (Unterhaltspglihten des Arbeitnehmers). In addition to these elements, social selection elements such as the prospects of dismissed employees in the labor market, occupational diseases, workplace injuries not caused by the employees themselves and severe disabilities must also be considered. The law requires the thorough consideration of social selection (ausreichende Berücksichtigung) rather than acompletely correct and ideal consideration. Labor Court judges must respect such considerable space ${ }^{64}$. According to Löwisch's viewpoint, if these three elements (the length of service, age of the employee and obligation of employee support) have already been considered and representatively evaluated, the related employers could be

\footnotetext{
${ }^{61}$ Vgl. auch LAG Düsseldorf vom 6.5.1977, DB 1977, 1370 für den Fall, daß eine Rationalisierungsmassnahme nur zum Wegfall eines Teils der Arbeitsaufgabe führt; ArbG Münster vom 8.12.1982, EzA §1 KSchG-Betriebsbedingte Kündigung Nr. 19.

${ }^{62}$ Vgl. BAG vom 20.21986 und vom 7.12.1978, EzA §1 KSchG Betriebsbedingte Kündigung Nr. 37 und 10.

${ }^{63}$ Jugend-oder Personalvertretung gemäss §9 IV 1 BpersVG; vgl. BVerwG 13.3.1989, 6 P 22/85 NVwZ-RR89, 373.

${ }^{64}$ Vgl auch von Prof. Löwisch eingefügte Fussnoten: BAG vom 18.10.1984, AP Nr.6 zu §1KSchG 1969 Sociale Auswahl+ DB 1985, 1083 = BB 1985, 1263 = NJW1985, 2046 = NZA1985, 423 = EzA§1KSchGBetriebsbedingte Kündigung Nr.34.
} 
considered part of the judges’ evaluation space (Löwisch, 2002: S. 352.) and the judges cannot accuse them of going against the provisions of social selection. The social selection standard could also be administered according to Article 95 (Löwisch, 2002: S. 176; Löwisch/Kaiser, 2010) of the Corporative Constitution, and could be provided in a collective agreement.

\section{Conclusion}

"Social rationality" or "social non-rationality" is a concept of legal technique. It not only needs continuing construction, but also differentiates from other similar general clauses in application. "Good customs” is explicitly stipulated in Article13 Section 2 of dismissal protection law and could be applied independently. Also because the idea of dismissal protection is not totally from Article 242 of Civil Code, the relationship between the principle of "good faith" and social non-reasonability of dismissal protection law is not the one between the general and special (keinlexgeneralis-lexspecialis-Verhältnis). Although the first sentence of Article1 Section 2 of Dismissal Protection Statute touches on the problem of social rationality but it merely mentions the categories of dismissal, while how to judge social rationality still depends on whether this dismissal reason accords with concrete social rationality. The first sentence of Article1 section 2 of Dismissal Protection Statute talked about "urgent enterprise need", but the word of "urgent” itself cannot become concrete reason that accords with "social rationality”. In the topic of this paper, the problems facing judge are how the judge continuingly construct and supplement the space which the legislator left intentionally. It cannot work if the judge uses the logical argumentation methods to apply in the space which legislator left intentionally, because in this space, the logical method of concept legal theory cannot replace completely the value evaluation of different interests. The existence space of legal factuality or substantiality is threaten in the conceptual logical method. And the attempts of German judge on the classification of connection of dismissal reasons (case type), which include the "sphere theory" proposed based on the "mixed compositions of facts” (Mischtatbestände), represent an effort to balance the contradictory elements in specific justice. But this is only the abstract classification by judges on the involved life facts within the scope of legislation space. And it is what the judges often do and is different from classic and iconic cases. We can consider that the categorization of dismissal reasons cannot find out the unification from diversity just like nature science does. Thus such measures still stay above the surface, and the essence of things is still waiting for digging up. However, the essence of things is actually the consensus of opinio juris (legal conviction) that participants share. We only need to confirm: these facts and conditions that need to be determined in advance do not equal to "the essence of things". The essence of things is actually the opinio juris that participants share, it can not be the legal source in Germany. Therefore it's deemed, that the legislator's space can not be continuingly constructed or supplemented merely based on the foundations of non-legal sources mentioned above. Thus we turn our view to "the principle of proportionality". The principle not only shows its objective instrumentality, but also inserts the meaning of equal treatment to inequality on this issue, and also the relationship between means and the end. And its function of showing balanced justice is precisely in line with the idea which the issue would resolve. However, no relevant specific reference data is available when we decide to set a targeted and applicable structure. But due to the restriction of setting conditions, such setting are often specific, it has different connotations in varying categories of dismissal by enterprise owner. With the help of the principle of proportionality to present and design a legal definite system is the core of the issue. Through this foregoing definite system, a legislative space of social rationality could be continuingly constructed or supplemented successfully by judges.

\section{References}

Alexy, R. (1979). Zum Begriff des Rechtsprinzips. In Rüthers/Fischer (Eds.), Rechtstheorie. München: C. H. Beck.

Arisoteles (1956). Nikomachische Ethik (V. Buch, 6. Kapitel 11316). Franz Dirlmeier, Berlin.

Bertelsmann, K. (1979). Aussperrung, Berlin.

Blomeyer, W. (1979). Das Übrmassverbot im Betriebsverfassungsrecht. In Gamillscheg/Hueck/Wiedemann, Hrsg., FS “25 Jahre Bundesarbeitsgericht”. München: C. H. Beck.

Brox, H./Rüthers, B. (1982). Arbeitskampfrecht. 2 Aufl., Stuttgart-Berlin-Köln-Mainz.

Coing, H. (1993). Grundzüge der Rechtsphilosophie. 5 Aufl., Berlin, Walter de Grugter.

Dornbusch/Fischermeier/Löwisch (2013). Fachanwaltskommentar Arbeitsrecht. 5 Aufl., Luchterhand Verlag. 
Emmerich/Habersack (1998). Aktienkonzernrecht, Kommentar. München: C. H. Beck.

Engisch, K. (1977). Einführung in das juristische Denken. 7. Aufl., Stuttgart-Berlin-Köln-Mainz.

Erman-Hanau, P. (1993). §626 BGB Handkommentar, 9. Aufl.

Fan, J. H. (2005). Procedure of German Constitution Court with the Proportion Principle concerning the Protection of Constitutional Rights. In Journal of Overseas Legal Studies, China Renda Social Sciences Information Center, No.2/2005.

Fitting/Auffarth/Kaiser/Heither (1987). Betriebsverfassungsgesetz. 15 Aufl., München: C. H. Beck.

Heck, P. (1914). Gesetzesauslegung und Interessenjurisprudenz, AcP 112.

Hedemann, J. W. (1933). Die Flucht in die Generalklauseln. Tübingen: J.C.B. Mohr.

Hedemann, J. W. (1933). Die flucht in die generalklauseln: Eine Gefahr für Recht und Staat. Tübingen: J.C.B. Mohr.

Hermann, H. (1982). Einführung in die Gesetzgebungslehre. Heidelberg.

Herschel-Löwisch (1984). Kommentar zum KSchG. 6 Aufl., Heidelberg.

Hillebrecht, W. (1985). dringende btriebliche Erfordernisse (§1 Abs.2 KSchG) zur Kündigung von Arbeitsverhältnissen durch den Konkursverwalter, ZIP.

Hirschberg, L. (1981). Der Grundsatz der Verhältnismässigkeit. Götingen.

Holly, H. G. (1989). Grundsatz der Verhältnismässiigkeit und Ultima-ratio-Prinzip im arbeitsvertraglichen Kündigungsrecht. Diss., Bonn.

Holmes Jr., O. W. (2011). The Common Law. University of Toronto Law School Typographical Society.

Hubmann, H. (1955). Grundsätze der Interessenabwägung, AcP, Bd 155.

Hueck, A. (1991). Gesellschaftsrecht. 19 Aufl., München: C. H. Beck.

Hueck/v. Hoyningen-Huene (1992). Kündigungsschutzgesetz. 11 Aufl., München: C. H. Beck.

Jakobs, M. C. (1985). Der Grundsatz der Verhältnismässigkeit, DVBl.

Joachim, H. (1973). Ist der Grundsatz der Verhältnismässigkeit ein geeignetes Kriterium für die rechtliche Erfassung des Phänomens “Arbeitskampf”? ArbuR.

Kässer, P. (1979). Vgl. die Formulierung von Petra Kaesser. Berlin: Der fehlerhafte Arbeitsvertrag.

Kempff (1978). Verhältnismässigkeit von Kündigung und Änderungskündigung-Ultima-ratio-Gedanke im Kündigungsschutzrecht, DB.

Knorr/Bichlmeier/Kremhelmer (1986). Die Kündigung und Formen der Beendigung von Arbeitsverhältnissen. 2 Aufl., München-Münster.

Kraus, R. (1995). Der Grundsatz der Verhältnismässigkeit in seiner Bedeutung für die Notwendigkeit des Mittels im Verwaltungsrecht. Hamburg.

KR-bearbeiter (2007). Gemeinschaftskommentar zum Kündigungsschutzgesetz und sonstigen kündigungsschutzrechtlichen Vorschriften. 8 Aufl., Neuwied. (zit.: KR/ Bearbeiter)

Lerche, P. (1961). Übermass und Verfassungsrecht, Köln-Berlin-Bonn.

Löwisch (1997). Arbeitskampf-und Schlichtungsrecht, Forker Verlag.

Löwisch (2002). Arbeitsrecht, 6. Aufl. Werner Verlag, Düsseldorf.

Löwisch, M. (1971). Das Übermassverbot im Arbeitskampfrecht, ZfA.

Löwisch/Caspers/Klumpp (2012). Arbeitsrecht. Ein Studienbuch. 9. Aufl.

Löwisch/Kaiser (2010). Kommentar zum Betriebsverfassungsgetz, 6.Aufl.

Löwisch/Spinner/Wertheimer (2013). Kommentar KSchG, 10., neubearbeitete und erweiterte Auflage.

Martens, K.-P. (1982). Das Arbeitsrecht der leitenden Angestellten, Schriften zur Arbeitsrecht-Blattei. Forkel.

Metzner, R. (1970). Das Verbot der Unverhältnismässigkeit im Privatrecht, Diss. Erlangen.

Müller, G. (1972). Fragen zum Arbeitskampfrecht nach dem Beschluß des Grossen Senats des BAG vom 21.4.1971, GewMH.

Müller, H. P. (1980). Aussperrung und Verhältnismässighkeit, DB. 1694.

Münch.-Komm.-Bearbeiter (1998). Münchener Kommentar zum Bürgerlichen Gesetzbuch, München (zitiert: Münch.Komm-Bearbeiter).

Nipperdey, Hans-Carl/Säcker, Franz-Jürgen, Anm. zum Vorlagebeschluß des 1. Senats des BAG vom 3.9.1968, AP Nr. 39 zu Art. 9 GG -Arbeitskampf. 
Palandt-Bearbeiter (2002). Bürgerliches Gesetzbuch, Kurzkommentar, 61. Auflage, München (zitiert: Palandt-Bearbeiter). Preis (1987). Prinzipien des Kündigungsrechts bei Arbeitsverhältnissen. München.

Ratajczak, T. (1984). Die Änderungskündigung des Arbeitgebers. Diss. Heidelberg.

Reuter, D. (1973). Die unverhältnismässige Aussperrung, JuS.

Reuter, D. (1975). Streik und Aussperrung, RdA.

Rieble, V. (1996). Arbeitsmarkt und Wettbewerb - Der Schutz von Vertrags- und Wettbewerbsfreiheit im Arbeitsrecht -Springer.

Rühers, B. (1972). Die Entwicklung des Arbeitskampfrechts unter besonderer Berücksichtigung der Rechtssprechung des Bundesarbeitsgerichts, ArbRGeg. Bd.10.

Rühers, B. (2002). Rechtstheorie. Verlag C. H. Beck OHG, Müenchen.

Säcker, F. J. (1972). Zu den rechtspolitischen Grundlagen der Arbeitskampf-Entscheidungen des Bundesarbeitsgerichts vom 21. April und 26. Oktober 1971, GewMH.

Schneider, E. (1972). Logik für Juristen, 2.Aufl., München.

Seiter, H. (1975). Streikrecht und Aussperrungsrecht, Tübingen.

Seiter, H. (1979). Arbeitskampfparität und Übermassverbot Düsseldorf-Frankfurt.

Siebert, H. (1960). Treu und Glauben im Kündigungsschutzrecht, in: BB.

Stahlhacke/Preis (1991). Kündigung und Kündigungsschutz im Arbeitsverhältnis, 5. Aufl., München.

Wank (1988). Arbeitnehmer und Selbständige, München.

Westermann, H. (1955). Wesen und Grenzen der richterlichen Streitentscheidung im Zivilrecht, Münster.

Wolf, E. (1953). Mass und Gerechtigkeit bei Solon. In: Gegenwartsprobleme des internationalen rechts und der Rechtsphilosophie Festschrift für R. Laun zum 70. Geburststag, Hamburg.

Wolter, J. (1980). Der Schutz des Arbeitnehmers vor betriebsbedingter Kündigung.

Zitscher, W. (1977). Der “verständige Betrachter” als Rechtsquelle-Wege und Grenzen richterlicher Erkenntnisse im Arbeitsrecht-ArbuR.

Zitscher, W. (1980). Der, “Grundsatz der Verhältnismässigkeit im Arbeitsvertragsrecht als Blankettformel”. BB, Heft 20.

Zöllner, W. (1963). Die Schranken mitgliedschaftlicher Stimmrechtsmacht bei den privatrechtlichen Personenverbäden, München und Berlin. 
Scientific Research Publishing (SCIRP) is one of the largest Open Access journal publishers. It is currently publishing more than 200 open access, online, peer-reviewed journals covering a wide range of academic disciplines. SCIRP serves the worldwide academic communities and contributes to the progress and application of science with its publication.

Other selected journals from SCIRP are listed as below. Submit your manuscript to us via either submit@scirp.org or Online Submission Portal.
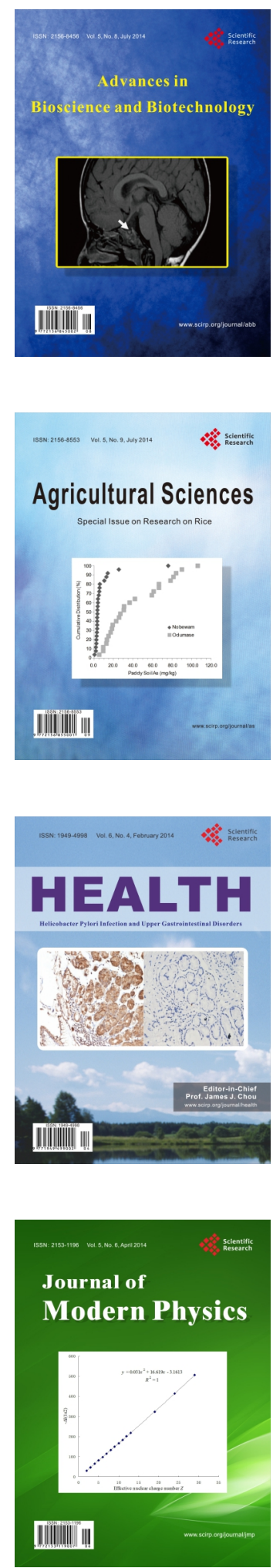
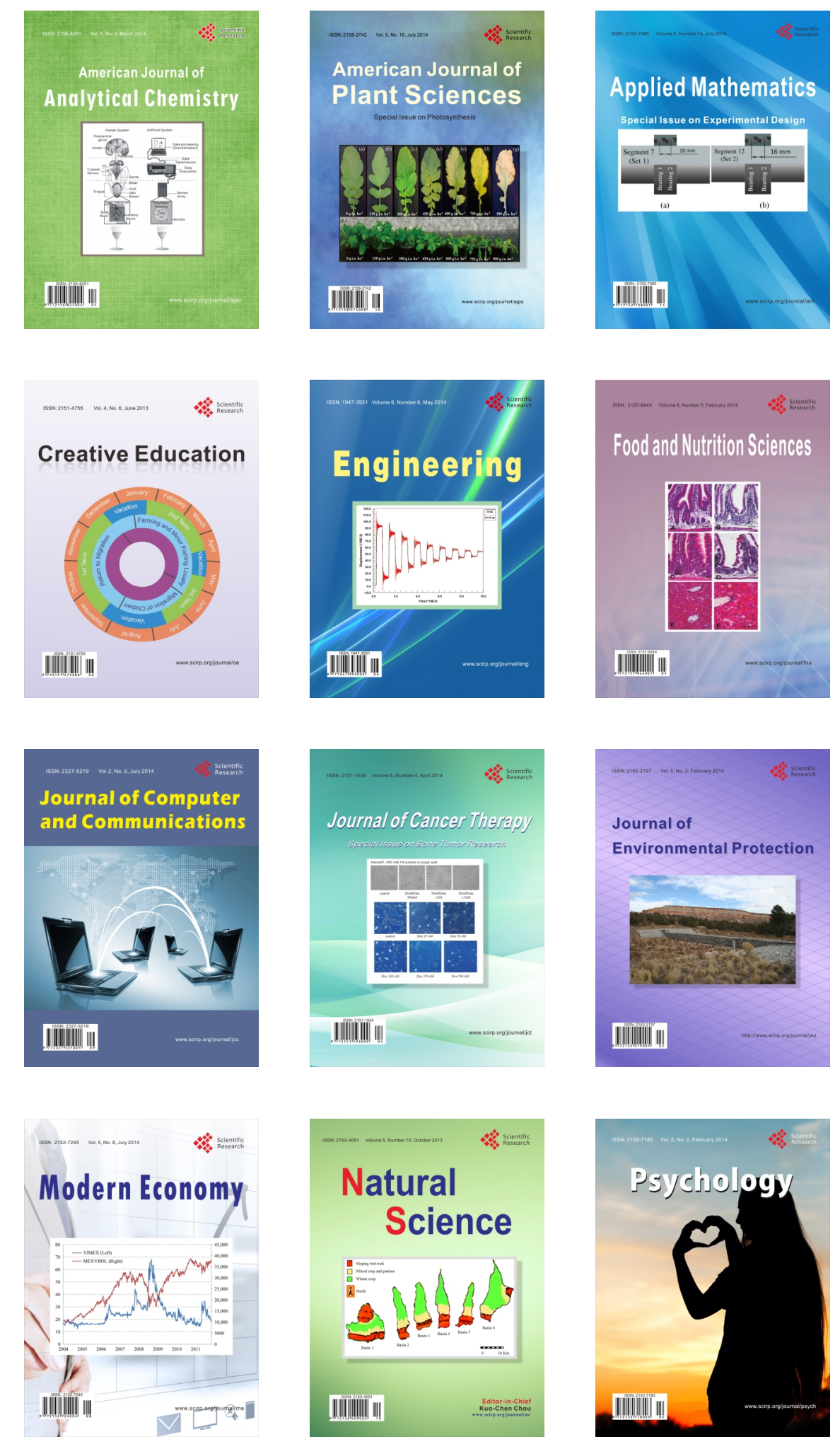